Омельковець, Руслана. «Західнополіські відфітонімні гастрономени». Лінгвостилістичні студії, вип. 11, 2019, c. 111-23.

Omelkovets, Ruslana. "Names of Dishes and Drinks Derived from Plant Names in Western Polissian Dialect". Linguostylistic Studies, iss. 11, 2019, pp. 111-23.

УдК 811.161.2'28(477.81/.82):641.5-027.553

https://doi.org/10.29038/2413-0923-2019-11-111-123

\title{
ЗАХІДНОПОЛІСЬКІ ВІДФІТОНІМНІ ГАСТРОНОМЕНИ
}

\author{
Руслана Омельковець \\ Східноєвропейський національний університет імені Лесі Українки, \\ Луцьк, Україна
}

Стаття присвячена дослідженню однієї з найстаріших лексико-семантичних груп української мови - лексики кулінарії, зокрема такої ії підгрупи, як назви страв та напоїв, що співідносні 3 найменуваннями рослин. Здійснено лексико-семантичний аналіз зафіксованих лексем. Показано їі структурні особливості, способи утворення таких гастрономенів та семантичні зміни, що при цьому відбуваються.

Ключові слова: лексема, гастрономени, фітономени, західнополіські говірки, семантичні моделі, номінативна варіативність, лексична варіативність.

\section{NAMES OF DISHES AND DRINKS DERIVED FROM PLANT NAMES IN WESTERN POLISSIAN DIALECT Ruslana Omelkovets \\ Lesya Ukrainka Eastern European National University, Lutsk, Ukraine}

The article deals with the investigation of Western Polissian dialect lexical structure which presents a particular interest as far as it concerns lexics reflecting different language changes in local dialect. Western Polissian dialects are the real treasure for Slavic phyilology. The article elucidates the lexical and topical group of the names of dishes and drinks which are ancient and worth of studying in the course of history of language, in particular semantic transformation as a result of metonymical changes based on botany lexics. The study has revealed basic semantic models. Food as a human everyday need reveals most people's everyday life, their characters and traditions, their nutrition preferences, limitations, and prohibitions, and therefore it is a valuable source for researchers. The relevance of the investigation is due to the lack of a systemic description of the thematic vocabulary group "foodstuff names" in the Western Polissian dialects.The purpose of the article is to describe the names of dishes and drinks that are related to the names of the plants on the material of Western Polissian dialect lexicon. The names of dishes and drinks in the Western Polissian dialect form a rich thematic group of vocabulary, the degree of representation and the nominative variability of which are different.The article analyzes more than 500 West Polissian food and drink names based on the names of the plants. One-word examples demonstrate typical for Ukrainian language ways of dish name formation and relevant semantic changes. The article contains examples of suffix derivatives formed from the names of food products and examples of names derived by lexical-semantic method. The main types of complex names of dishes are mostly two-part phrases. The typical structures are

(с) Омельковець Р., Східноєвропейський національний університет імені Лесі Українки, 2019.

Це стаття відкритого доступу на умовах СC BY-NC 4.0 
substantive phrases with subordinate words expressed by adjectives, participles, and nouns with prepositions. In most cases subordinate elements regardless of the grammatical form denote necessary ingredients of the dishes and methods of food processing or cooking. The repertoire of names testifies the formal variation of the Western Polissian dialect at the phoneme, accent, and grammar levels. A characteristic feature of the analyzed group of words is a wide range of synonyms for many concepts. As usual several terms are used in one locality or even in the sppeech of one and the same respondent, refering to the same phenomenon. Most names have several phonetic, morphological or accentuated variants.

Key words: thematic vocabulary group, names of dishes and drinks, Western Polissian dialect, ways of nomination, semantic models, nominative variability, lexical variability, derivation.

Вступ. Актуальним завданням сучасної лінгвістики i до нині залишається вивчення лексичного складу місцевих територіальних діалектів, оскільки лексика, як відомо, належить до найдинамічніших лінгвальних систем. Значний інтерес для такого дослідження становить територія Західного Полісся. Цей регіон і сьогодні зберігає справжні скарби для славістики. Важливе значення для мовознавчої науки мають назви, пов'язані з їжею. Їжа як повсякденна потреба людини найповніше розкриває щоденне життя народу, його побут, традиції, харчові вподобання, обмеження й заборони, тому найменування страв та напоїв $\epsilon$ цінним джерелом для науковців. Лексико-семантична група «їжа» має широкі синтагматичні зв'язки, але, за словами 3. Козирєвої, поки що залишається найменш дослідженою. Тематичну групу лексики (далі - ТГЛ) «Назви їжі» детально вивчено у східнополіських (Турчин), східностепових (Загнітко) та буковинських (Борис) говірках. Грунтовні дослідження цих тематичних груп здійснено на матеріалі південнолемківських (Ганудель), закарпатських (Гоца), східнослобожанських (Волошинова) говірок та у говірках надсянсько-наддністрянського суміжжя (Різник). Аналіз їжі на матеріалі говірок Прип'ятського Полісся здійснила білоруська дослідниця Г. Вештарт. Актуальність розвідки зумовлено відсутністю системного опису ТГЛ «Назви їжі» в українських західнополіських говірках.

Мета статті - здійснити опис назв страв та напоїв, співвідносних із найменуваннями рослин, на матеріалі українських західнополіських говірок. Поставлена мета передбачає розв'язання таких завдань: 1) здійснити лексико-семантичний аналіз зафіксованих лексем; 2) показати структурні особливості цієї лексико-тематичної групи; 3) встановити способи утворення таких гастрономенів та семантичні зміни, що при цьому відбуваються.

Матеріал i методи дослідження. Джерелами дослідження послужили власні польові записи, здійснені за спеціально укладеною програмою. У роботі використано метод компонентного аналізу (для з'ясування семантичної структури опорних лексем) та метод кількісних підрахунків, що уможливив визначення номінативної та лексичної варіативності досліджуваної терміносистеми. 
Результати дослідження та дискусія. Актуальною на сьогодні залишається проблема лексико-семантичної еволюції лексики за певними моделями. Відомо, що одним із шляхів створення нової номінативної одиниці $\epsilon$ надання готовій лексемі нової семантичної функції (опосередкований спосіб номінації) (Блинова 99). За рахунок такого метонімічного перенесення значною мірою поповнюється і лексика кулінарії. Метонімія як лексико-семантична трансформація слова базується на вживанні замість одного слова іншого, яке перебуває в синтагматичному, контекстному зв'язку з першим (Шмелев 62), тобто в певному асоціативному зв'язку за логічною суміжністю.

Лексико-тематична група «Назви страв та напоїв, співвідносних із назвами рослин», що об'єднує такі тематичні мікрогрупи, як «Назви овочевих страв», «Назви рідких страв, основними інредієнтами яких $\epsilon$ рослинні продукти», «Назви страв із крупів», «Випічка, до складу якої входять продукти рослинного походження», «Назви напоїв, основними інредієнтами яких $\epsilon$ рослинні продукти», «Назви приправ та спецій», репрезентує номінації страв, співідносні із назвами культурних рослин, які найчастіше вирощують на вказаній території (картопля, капуста, буряк, морква, цибуля, бобові, горох, гречка, овес, ячмінь, жито, рис, мак, гарбуз, калина, малина, ожина та ін), та деяких дикорослих, які традиційно на Західному Поліссі вживалися в їжу (кропива, лобода та ін.). Такі гастрономени постали внаслідок внутрішньопарадигматичного перенесення значення за схемою «назва рослини > назва продукту > назва страви»:

«назви страв» < картопля 'картопля (Solanum tuberosum L.)' 'однорічна трав'яниста рослина з їстівними бульбами, багатими на крохмаль' (Словник 4: 112): карто́nли (Ворокомле) (далі після ілюстративного матеріалу в дужках вказуватимемо назву населеного пункту, в якому зафіксована наведена лексема), карто́nли мну́ти (Ворокомле), карто́nл'a мн'áma, карто́nл'a ва́рана (Несвіч), карто́nл'a то́ўчана (Брониця, Осівці) 'картопля м’ята'; карто́пли ту́шани (Воєгоща), карто́nл'a ту́шана (Ворокомле, Піщане) (карто́nл'a ти́шина (Несвіч), ту́шана карто́nл'a (Пнівне)), ту́шана карто́шка (Ратнів) 'тушкована картопля'; п’ічо́не карто́nле (Пнівне); карто́nл'а в лушпи́н':i (Воєгоща, Камінь-Каширський, Осівці), карто́пли в лушпа́і̌ках (Видерта), карто́пле в мунд'і́рах (Пнівне) 'варена або печена картопля, з якої не знято шкірку'; картопл'а́ник'i (картопл'е́ники) (Соснівка, Світязь) 'млинці 3 тертої картоплі'; картопл'а́нка (Чаруків) 'тушкована картопля; картоп'л'анка (Сошичне) 'картопляна юшка'; картупл'е́ник 'пиріг з картоплею' (Ворокомле); картопл'а́ники (Зарічне, Ківерці), п'іроги́ з карто́nли (Воєгоща) 'млинці 3 картоплі; картопл'а́ники (Зарічне) 'млинці 3 картопляного пюре 3 начинкою'; картопл'а́ники з гриба́ми (Кадище) 'млинці з картоплі та грибів'; картопл'а́ники (Чаруків), картопл'а́н'i кл'о́цки (Чаруків) 'галушки з картоплі'; < бульба - 'діал. картопля' (Словник 
1: 254; Аркушин, 35; Омельковець, 36): бу́л'ба (Видерта, Ворокомле, Грудки, Піщане), бу́л'ба мну́та (Видерта, Ворокомле), коло́чена бу́л'ба (Світязь) 'картопля м’ята'; карто́пли жа́рани (Пнівне) (карто́пл'а жа́рена (КаміньКаширський)) 'картопля смажена'; ту́шана бу́л'ба (Майдан-Липненський, Рудня) 'тушкована картопля'; бу́л'ба в мунд'і́рах (Ворокомле, МайданЛипненський, Рудня) 'варена картопля, 3 якої не знято шкірки'; бул'б'і́вники (Ратне) (бул'бо́вники (Ворокомле)), бул'ба́ники (Підцаревичі) (бул'б'а́ник'i (Хотешів)), бул'бовики́ (Самари), бул'бе́вники (Видерта) 'млинці з картоплі'; бул'ба́ник (Погулянка) 'пиріг з картоплею'; бул'ба́ники (МайданЛипненський, Тинне) 'млинці з тертої картоплі'; бул'бо́вники (Волиця, Воля) 'млинці з картоплі та бобу'; бул'бо́нчик (Видерта) 'тушкована картопля'; < капуста 'капуста городня (Brassica oleracea L.)' - 'городня рослина родини хрестоцвітих, листя якої використовують для виготовлення різних страв' (Словник 4: 82): капусн'а́к (Мар'янівка, Гряди, Самари, Світязь), боршч з ки́слойі капи́сти (Тинне) 'борщ із капусти' 'страва, зварена переважно 3 квашеної капусти 3 додаванням інших продуктів' (Словник 4: 98); го́лий капу́сник 'пісний борщ із капустою' (Чаруків); капусн'а́к (то в нас ти́л'ки з ри́сом / лини́в'і голубщи́ ка́жут' menép / то не боршч (Майдан-Липненський)); капуст'а́ник (Тур) 'запечена капуста'; капуст'а́ники (Мельники) 'смажена капуста'; ту́шана капу́ста 3 púcoм 'тушкована капуста $з$ рисом' (Окачеве); пече́на капу́ста (Самари) 'печена капуста'; капуст'а́ники (Кадище, Луків) 'млинці з капустою'; капуст'а́ник'i (Березне, Старий Чорторийськ) (капуст'е́ники (Ворокомле)), капу́сн'ік'i (Видерта), капусн'аки́ (Воєгоща), n’ip'íz з капу́стойу (Пнівне), n'iроги́ з капи́стойу (Дольськ), капуст'а́н'і пироги́ (Погулянка) (капуст'а́ни пироги́ (Рудня)), пирошк'í капу́стн'i (Майдан-Липненський) 'пироги 3 капустою'; < квасоля 'квасоля (Phaseolus L.)' - 'городня трав'яниста однорічна рослина родини бобових, плоди якої вживають для їжі' (Словник 4: 132) (б’іб - 'діал. квасоля' (Аркушин, 18; Омельковець, 26); пасо́л'а - 'діал. квасоля' (Аркушин, 383; Омельковець, 141)): бобо́виц звар (Видерта), бобовйа́нка (Воєгоща) (бубувйе́нка (Ворокомле)), 'юшка 3 квасолі'; боб'і́вники (квасоля) (Самари, Тур) (бобо́вники (Залізниця)) 'млинці 3 картоплі та квасолі'; буб'і́вники (Окачеве) 'вареники з квасолею'; боби́вники (Окачеве), пироги́ з пас'о́луйу (Тинне) 'пироги з квасолею'; квасол'а́нка (Волиця) 'настоянка з квасолі'; т'уфте́л'ки з квасо́л'і (Ратне), шпарад'і́вка (Чаруків) 'салат із квасолі', пасо́л'ова йу́шка (Майдан-Липненський), пасо́л'а p'і́дка (Старий Чорторийськ), суп з бубо́м (Пнівне), квасоле́вий суп (Березне) 'суп із квасолею'; боршч з бобо́м 'борщ із квасолею' (Окачеве); < горох 'горох посівний (Pisum sativum L.)' - 'польова і городня тран'яниста рослина родини бобових із круглим насінням (горошинами), що використовується для харчування' (Словник 2: 137): горох (Брониця, Воєгоща, Грудки, Осівці, Піщане, Соснівка, Сошичне), гуро́х ва́раний (Видерта, Ворокомле), горохо́вка (Ратне) 'каша з гороху'; горохо́внек (Ворокомле) (горохе́вник (Видерта)), горо́ховиі̆ суn (Березне) (горо́хов'ї̌ суn 
(Воєгоща)) 'суп із горохом'; < буряк 'буряк (Beta vulgaris)' - 'корінь цієї рослини вживається як їжа' (Словник 1: 262): бурача́ник (Видерта) (бураче́ник (Ворокомле)), бур'ача́ниі̆ боршч (Погулянка), боршч з бурака́ (Пнівне), боршч з бурачка́ мулуде́і̌кого (Воєгоща), боршч з нате́ни (Воля), боршч з бур'ако́войі нати́ни (Самари) 'борщ із листя або коренеплодів буряка'; бурача́нка (Воєгоща) (бураче́нка (Борбин, Пнівне, Погулянка, Рудня, Старий Чорторийськ)) 'алкогольний напій із цукрових буряків', ква́ша буракова́ 'напій із цукрових буряків'; < гречка 'гречка посівна (Fagopyrum esculentum L.)' - 'однорічна трав'яниста медоносна рослина, із зерен якої виготовляють високопоживну крупу та борошно' (Словник 2: 164): гре́чка (Видерта, Воєгоща), греча́ний кис'і́л' (березне) 'каша з гречаної крупи', греча́ники (Воєгоща, Волиця, Ворокомле, Гряди, Зарічне, Колодеже, Майдан-Липненський, Носарево, Пнівне, Самари, Світязь,), греча́нки (Воєгоща) 'котлети з гречки', греча́ники (Гряди) 'млинці з вареної гречки', греча́ниі̆ суп (Світязь) 'суп із гречаною крупою'; < щавель 'щавель (Rumex)' - 'трав'яниста, перев. багаторічна рослина родини гречкових, стебло й продовгувате листя якої здебільшого має кислий смак; використовується в кулінарії' (Словник 11: 570): шчаву́х, чавйу́х, шчавійі́ - 'діал.щавель' (Омельковець 201); шчавле́виі̆ боршч (Березне, Самари), (шчавл'о́виі̆ боршч (Волиця), шчавйо́вий боршч (Торчин), шчавл'о́ви боршч (Тинне), шчаву́шн'іĭ боршч (Світязь) (шчаву́шний боршч (Луків)), боршч із шчавл'á (Тинне), боршч з чавйухо́м (Окачеве), щаве́л'ник (Ратне) 'зелений борщ'; < овес 'овес (Avena)' (увес - 'діал. овес' (Омельковець 132); > вівсянка - 'борошно або крупа, виготовлені з вівса; вівсяна каша або юшка' (Словник 1: 550): в'івс'а́ник (Воєгоща) (вувс'е́ник (Видерта), увс'е́ник (Ворокомле), овс'а́ник (Майдан-Липненський)), в'іс'а́ники (Гряди) (овс'а́ник'i (Погулянка, Старий Чорторийськ)), в'івс'а́н'i пр'а́н'ік'i (Пнівне) 'вівсяне печиво'; в'івс'а́на ка́ша (Камінь-Каширський) (вус'а́на ка́ша (Торчин)) 'вівсяна каша'; в'івс'а́ниц кис'і́л' 'кисіль із вівсяного борошна' (Самари); < рис 'рис (Oryza sativa)' 'трав'яниста рослина родини злакових, зерна якої є цінним харчовим продуктом' (Словник 8; 538): рис (рес) (Видерта, Ворокомле, Торчин) 'рисова каша'; рис'і́вниц'а (Ряди) 'рис з овочами'; < ячмінь 'ячмінь (Hordeum vulgare)' - 'злакова рослина, зерна якої використовують для виготовлення круп та борошна' (Словник 11: 661): йачм'і́нка (Соснівка), йачм'і́н:а ка́ша (Воєгоща) 'каша $з$ ячменю'; < жито 'жито (Secale cereale)' > житнівка 'житнівка горілка, приготовлена з хліба, зерна (перев. жита)' (Словник 11: 683): житн'і́вка (Березне) 'горілка 3 жита'; житн'е́к 'житній хліб' (Видерта); < мак 'мак (Papaver rhoeas L.)' - 'трав'яниста рослина, що вирощується як лікарська та олійна культура' (Словник 4: 601): макувне́к (Ворокомле), маковник'і́ (Погулянка) (макувник'і́ (Воєгоща)) 'млинець 3 маком'; мак'івни́к (Світязь, Чаруків) (маковни́к (Щедрогір)) 'пиріг з маком'; < цибуля 'цибуля (Allium)' - 'овочева городня рослина 3 їстівною цибулиною і їстівним трубчастим листям' (Словник 11: 206): цибу́л'ники (Княгининок, Мар'янівка, Ратне, Самари), цибул'а́ники (Борбин) 'млинці 3 
цибулі'; < морква 'морква (Daucus)' - 'городня рослина 3 пірчасторозсіченими листками й довгастим потовщеним коренем, що вживається як їжа' (Словник 4: 803): моркв'а́ний торт (Самари), моркв'а́ний пл'а́цок (Ратне) 'випічка'; моркв'а́ники (Княгининок) 'млинці з моркви'; < гарбуз 'гарбуз (Cucurbita)' - 'городня сланка рослина з великими круглими або овальними плодами' (Словник 2: 30): гарбузо́ва ка́ша (Самари), гарбуз'е́нка (Ворокомле) 'каша із гарбузи'; гарбу́зник (Щедрогір) 'суп із гарбузи'; < яблуня 'яблуня (Malus)' > яблуко 'плід яблуні' (Словник 11: 619): йа́блучник (Видерта, Ворокомле, Гряди), пири́г йа́блучни (МайданЛипненський), n'ірог'é з йа́блуками (Окачеве) 'пиріг з яблук'; йалуча́ники (Княгининок) 'млинці з яблук'; < кропива 'кропива дводомна (Urtica dioica L.)' - 'трав'яниста рослина, стебло та листя якої густо вкриті жалкими волосками' (Словник 4: 365): копивйа́ники (Борбин) 'млинці з кропиви'; < черемша 'цибуля ведмежа (Allium ursinum)': черемша́ник (Носарево) 'салат із черемші'; < лобода 'лобода біла (Chenopodium album L.)': свир'і́бка (cвир'і́na - 'діал. лобода біла' (Пнівне)), боршч з либ’іди́ (Пнівне) 'борщ 3 лободи';

«назви приправ, співвідносних із назвами рослин» < петрушка 'петрушка (Petroselinum)' - 'дворічна, зрідка однорічна городня пряна овочева рослина родини зонтичних, коренеплоди та листочки якої використовують як приправу для їжі' (Словник 6: 345): петру́шка (питру́шка, n’ітру́шка, петру́ха (Омельковець 143); < кріп 'кріп городній чи пахучий (Anethum graveolens L.)' - 'однорічна городня рослина родини зонтичних, що її використовують як ароматичну приправу для страв, а також для соління огірків і помідорів' (Словник 4: 356): кр'іп (Брониця, Воєгоща, Грудки, Гряди, Дольськ, Осівці) (крип (Піщане, Соснівка), укро́n (Брониця, Воєгоща, Камінь-Каширський), укро́n, укр'ín, окр'ín, окрón, кр'in, кроп (Омельковець 188)), кпупе́u' (Видерта, Ворокомле); < м'ята 'м'ята перцева (Mentha piperita L.)' - 'багаторічна трав'яниста запашна рослина родини губоцвітих' (Словник 4: 839): мйáma (мн’áma, мйámва, мйатва́, мн'е́тва) мйáma перце́ва, мйáma холо́дна (Омельковець 117), мйа́тка (мн'ámка (Омельковець 118)), паху́чка (Омельковець 141), бу́квиц'a (Омельковець 36), г’ірча́к (Омельковець 49); < часник 'часник городній (Allium sativum L.)'- 'овочева городня рослина з різким смаком і запахом, що вживається як страва та приправа' (Словник 11:277): часни́к (ч'існо́к, чусно́к, чусни́к, часне́к (Омельковець 194); < цибуля 'цибуля (Allium)' 'овочева городня рослина з їстівною цибулиною і їстівним трубчастим листям' (Словник 11: 206): цибу́л'а (цибу́ла, цебу́л'а (Омельковець 193); < перець 'перець овочевий, або паприка (Capsicum annuum)' - 'овочева напівкущова або трав'яниста рослина, пряні плоди якої використовуються для їжі або як приправа' (Словник 6: 318). пе́рец' (усі обстежені населені пункти) (пе́риц' (Видерта, Ворокомле)); < гірчиця 'гірчиця біла (Sinapis $a l b a)^{\prime}$ - 'трав'яниста олійна рослина з родини хрестоцвітих. Приправа до страви' (Словник 2: 76). гурче́ц'a (Видерта, Ворокомле); < хрін 'хрін 
звичайний (Armoracia rusticana)'- 'корінь цієї рослини вживається як гостра, пряна приправа до їжі' (Словник 11: 149): хр'ін (усі обстежені населені пункти) (хрин (Видерта, Ворокомле), хр'ін, хрон (Омельковець 192)); < меліса 'меліса лікарська (Melissa officinalis L.)' - 'трав'яниста багаторічна медоносна рослина, яку застосовують як спецію при засолюванні помідорів і огірків' (Словник 4: 669): ме ил'і́са (Омельковець 124), кади́ло (Омельковець 8), кото́вник (Омельковець 100), л'е́скавка, лимо́нка, лимо́н:а мйа́та, лимо́н:а трава́ (Омельковець 112), мйа́та (мн'áma) (Омельковець 117), мйámка, мйáточник (Омельковець 118), ма́точник (ма́тучн'ік) (Омельковець 122), мед'і́вка (Омельковець 96), мед'івни́к, ме д'івни́ц'а, л'ісова́ медо́ва трава́ (Омельковець 122), пахн'у́чка (Омельковець 141), ройови́к (Омельковець 162);

«назви напоїв, пов'язані з найменуваннями рослин» < жито 'жито (Secale cereale)' > житнівка - 'горілка, приготовлена з хліба, зерна (перев. жита)' (Словник 11: 83): же́тн'івка (Соснівка); < зубрівка (зубр'і́вка 'чаполоч пахуча (Hierochloe odorata Wahlb)' (Омельковець 83) - 'дикоросла трав'яниста рослина родини злакових; настояна на цій траві горілка' (Словник 3: 728): зубро́вка (Видерта, Ворокомле); < калган 'перстач прямостоячий (Potentilla erecta Räeusch.) кол'гáн - 'діал. калган' (Волиця) > калганівка - 'горілка, настояна на калгані' (Словник 4: 76): калга́н'івка (Видерта, Зарічне, Самари), кол'га́нка (Волиця); < калина 'калина звичайна, або червона калина (Viburnum opulus L.)' > калинівка 'горілка, настояна на ягодах калини; калинова наливка' (Словник 4: 760: кали́н'івка (Борбин, Гряди, Соснівка); < вишня 'вишня (Cerasus)' > вишнівка 'вишнева наливка' (Словник 1: 543): вишн'а́к (гряди, Колодеже) (вишн'е́к (Воєгоща)), вишн'о́вка (Воля), вишн'а́нка (Старий Чорторийськ) 'настоянка з вишень'; вишн'і́вка 'самогонка з вишень' (Стенжаричі); < ожина 'ожина сиза або звичайна (Rubus caesius L)' > ожинівка - 'наливка 3 ожини' (Словник 5: 648): ожи́н'івка (Воєгоща) (вже́нувка (Видерта, Ворокомле), уже́нувка (Ворокомле)); ожии́н:ики (Гряди) 'пиріжки з ожиною'; < малина 'малина європейська (Rubus idaeus)' > малинівка - 'наливка з ягід малини' (Словник 4: 607): мали́н'івка (Борбин, Гряди) (мали́нувка (Грудки), мале́нувка (Ворокомле)); < груша 'груша (Ругіnae)' > грушівка - 'грушева наливка' (Словник 2: 183): груш'і́вка (Осівці); < перець 'перець овочевий, або паприка (Capsicum annuum)' > перцівка - 'горілка, настояна на перці' (Словник 6: 335): перцо́вка (Брониця); < полин 'полин гіркий (Artemisia absinthium L.)' > полинівка - 'горілка, настояна на полину' (Словник 7: 68): поли́н'івка (Камінь-Каширський, Самари) 'горілка з полину'; < абрикос 'абрикос (Prunus armenica)' > абрикосівка - 'горілка, настояна на абрикосах' (Словник 1: 5), абрико́с'івка (8); < слива 'слива домашня або звичайна (Prunus domestica)' > слив'янка - 'сливова наливка або настойка на спирті, горілці і т. ін.' (Словник 9: 351): сливйа́нка (Воєгоща, Старий Чорторийськ) (сливйе́нка (Грудки)); агрус 'агрус (Ribes uva-crispa)' > агрусівка - 'наливка або настоянка з агрусу' (Словник 1: 18): агрус'і́вка (Камінь-Каширський); < 
клюква (кл'у́ква 'журавлина болотна (Oхусоссиs palustris Pers.)' (Омельковець 93) > клюквівка: кл'у́кв'івка 'напій з клюкви' (Зарічне); кл'у́кв'івка (Зарічне) 'настоянка з клюкви'; < терн 'терен звичайний (Prunus spinosa L.)' > тернівка: терну́вка (33) 'настоянка з терну'; < шипшина 'шипшина собача (Rosa canina L.)' > шипшинівка: шипши́н'івка (Самари) 'настоянка 3 шипшини'; < кульбаба 'кульбаба лікарська (Taraxacum opficinale webb. L.)': кул'бáбове варе́н':a (Любомль) 'варення 3 квітів кульбаби', кул'ба́бка (Кадище) 'настоянка з квітів кульбаби'; < пшениця 'пшениця (Triticum L.)': пшени́чний квас (Самари); < троянда 'троянда (Rosa L.)': тройа́ндове варе́н':a (Любомль, Самари), варе́н':a 3 тройа́ндових пел'у́сток (Самари); < хміль 'хміль звичайний ( Humulus lupulus)': пи́во 3 хме́л'у (Самари); < липа 'липа серцелиста (Tilia cordata Mill.)': ли́повиц̌ чац̌ (Зарічне); < обліпиха 'обліпиха крушиновидна (Hippophae rhamnoides L.)': обл'іпи́шник (Гряди) 'чай з обліпихи'; < хрін 'хрін звичайний (Armoracia rusticana)': хр'інову́ха (Гряди) 'алкогольний напій із хрону'; < черемха 'черемха звичайна (Prunus padus)': компо́т з черему́хи (Колодеже) 'напій із черемхи'; < чорниця 'чорниця звичайна (Vaccinium myrtillus L.)': кампóm 3 йе́гуд (Пнівне) 'напій із чорниць'.

Загальна кількість проаналізованих назв становить близько 500. Кількість номенів для позначення реалій варіює від 1 (напр.: рис'і́вниц'a 'рис 3 овочами'; житн'і́вка 'горілка 3 жита'; житн'е́к 'житній хліб'; цибул'а́ники 'млинці з цибулі') до 5 (напр.: 'картопля м'ята' - карто́nли, карто́пли мну́ти, карто́пл'а мн'áma, карто́nл'а ва́рана, карто́nл'а то́уччана).

Одна страва може мати декілька назв (напр.: 'борщ із капусти' капусн'а́к, боршч з ки́слойі капу́сти; 'пироги з капустою' - капу́сн'iк'i, капуст'е́ники, капусн'аки́, капуст'а́ник'i, n'ip'íz з капу́стойу, n'іроги́ 3 капу́стойу, капуст'а́н'i пироги́, капуст'а́ни пироги́, пирошк'і́ капу́стн'ї; 'суп із квасолею' - пасо́л'ова йу́шка, пасо́л'а р'і́дка, суп з бубо́м, квасоле́вий суп) і навпаки різні страви можуть іменуватися однаково (напр.: картопл'а́ники 'млинці з картоплі, 'млинці з картопляного пюре з начинкою', 'галушки 3 картоплі'; бураче́нка 'страва із листя буряка', бурача́нка 'алкогольний напій, виготовлений із буряків'; боб'і́вники (квасоля) 'млинці з картоплі та квасолі'; буб'і́вники 'вареники з квасолею'; боби́вники 'пироги з квасолею').

Зіставлення або вияв номенів у різних говірках засвідчив їх формальне варіювання в межах досліджуваних говірок на фонемному, акцентному та граматичному рівнях; переважають фонемні варіанти, акцентних та граматичних варіантів зафіксовано значно менше, напр.: бул'б'ївники (бул'бо́вники), бул'ба́ники (бул'б'а́ник'i), бул'бовики́, бул'бе́вники; бобовйа́нка (бубувйе́нка); бобо́вники (боб'і́вники); горохо́внек (горохе́вник); горо́ховий суп (горо́хов'ї̌ суп); бурача́ник (бураче́ник); шчавле́вий боршч (шчавл'о́вий боршч, шчавйо́вий боршч, шчаву́шн'іі̆ боршч, шчавл'о́ви боршч, шчаву́шниц боршч); в'івс'а́ник (вувс'е́ник, увс'е́ник, овс'а́ник); мак'івни́к (маковни́к, макувни́к); кр'іn (крип, укро́n, укр'ín, окр'і́n, окро́n, кр'in, кроп). 
Варіативність номінацій зумовлена кількома чинниками: реалізацією різних мотиваційних ознак при номінаціях; впливами інших мов; внутрішньоговірковими трансформаціями номінації.

Структурно зафіксовані назви поділяються на дві великі групи: 1) однослівні найменування; 2) складені найменування, що $\epsilon$ полікомпонентними (здебільшого двокомпонентними) словосполученнями. Однослівні назви страв засвідчують типові для української мови способи утворення назв страв та семантичні зміни, що при цьому відбуваються, якот: 1) суфіксальні утворення від назв продукту: «назви страв» картопл'а́ник'i, картопл'а́нка, картупл'е́ник, бул'бо́вники, бул'ба́ники, бул'б'і́вники, бул'б'а́ник'i, бул'бовики́, бул'бе́вники, бул'ба́ник, бул'ба́ники, бул'бо́вники, бул'бо́нчик, капусн'а́к, капуст'а́ник, капуст'а́ник'i, капуст'е́ники, капу́сн'ік'i, капусн'аки́, бубувйе́нка, бобовйа́нка, бобо́вники, боб'і́вники, буб'і́вники, боби́вники, квасол'а́нка, шпарад'і́вка, горохо́вка, горохе́вник, горохо́внек, бурача́ник, бураче́ник, бурача́нка, бураче́нка, греча́нки, греча́ники, шчаве́л'ник, в'івс'а́ник, вувс'е́ник, в'іс'а́ники, увс'е́ник, овс'а́ник, овс'а́ник'i, рис'і́вниц'а, житн 'і́вка, житн'е́к, макувне́к, макувник'í, маковник'í, мак'івни́к, маковни́к, цибу́л'ники, цибул'а́ники, гарбуз'е́нка, гарбу́зник, йа́блучник, йалуча́ники, копивйа́ники, черемша́ник, же́тн'івка, зубро́вка, калга́н'івка, кол'га́нка, кали́н'івка, вишн'а́к, вишн'е́к, вишн'і́вка, вишн'о́вка, вишн'а́нка, ожи́н'івка, вже́нувка, уже́нувка, ожии́н:ики, мали́н'івка, мали́нувка, мале́нувка; груш'і́вка, перцовкка, поли́н'івка, абрико́с'івка, сливйа́нка, сливйе́нка, агрус'івка, кл'у́кв'івка, терну́вка, шипши́н'івка, кул'ба́бка, обл'іпи́шник, хр'інову́ха; отже, більшість броматономенів утворено від іменних (переважно іменникових - назви рослин) основ шляхом суфіксації, яка вказує на релятивне відношення до інших назв, на базі яких виникли ці лексеми; до найпродуктивніших суфіксів у творенні відсубстантивних похідних належать: -к-, -ик- (-ік-), -ник-, -анк- (-енк-), -івк$(-у в к-,-о в к-) ;$ малопродуктивними $\epsilon$ суфікси: -ак (-ек-), -ух-, -ниц'-; 2) найменування, утворені лексико-семантичним способом; це назви страв та напоїв, співвідносні з назвами городньої та садової продукції, які збігаються 3 ботанічними найменуваннями самих рослин (передусім ідеться про вживання в ролі назв страв найменувань продуктів - назв рослин): карто́пли, бу́л'ба, гре́чка, рис, горох, кпупе́ч', кр'іп, мйа́та, часни́к, цибу́л'а, пе́рещ', гурче́u'a, хр'ін, меил'і́са. Серед них переважають двоскладні словосполучення. Основними типами двоскладних структур $\epsilon$ такі: іменниково-прикметникові (дієприкметникові), іменниково-іменникові. Словосполучення 3 головним словом - іменником і залежним прикметником або дієприкметником поділяємо на групи залежно від семантики залежного компонента: 1) найбільшу кількість становлять словосполучення, у яких залежний прикметник вказує на продукт, який $\epsilon$ або основним інгредієнтом страви, або тим компонентом, який надає страві особливого смаку: картопл'а́н'i кл'о́цки, капуст'а́н'i пироги́ (капуст'а́ни пироги́), пирошк'і́ капу́стн'i, бобо́виі̌ звар, пасо́л'ова йу́шка, 
горо́хов'їі суп, горо́ховиі̆ суп, бур'ача́ний боршч, ква́ша буракова́; греча́ний кис'і́л', греча́ний суп, шчавле́виі̆ боршч (шчавл'о́вий боршч, шчавйо́вий боршч, щаву́шн'іци боршч, шчавл'о́ви боршч, шчаву́шний боршч), в'івс'а́н'і пр'а́н'iк'i, в'івс'а́на ка́ша (вус'а́на ка́ша), в'івс'а́ний кис'і́л', йачм'їн:а ка́ша, моркв'а́ний торт, моркв'а́ний пл'а́цок, гарбузо́ва ка́ша, пири́г йа́блучни, кул'ба́бове варе́н':а, пшени́чний квас, тройа́ндове варе́н':a, ли́повий чай; 2) ряд складених найменувань являють собою словосполучення іменників із залежними дієприкметниками, які вказують на види кулінарної або механічної обробки продуктів: карто́nли мни́ти (карто́nл'а мн'áma), карто́nл'a ва́рана, карто́nл'а то́уччана, карто́nл'а ту́шана (карто́пли ту́шани, карто́nл'а ту́шина, ту́шана карто́nл'а, ту́шана карто́шка), п’ічо́не карто́nле, бу́л'ба мну́та, коло́чена бу́л'ба, карто́пл'а жа́рена (карто́пли жа́рани), ту́шана бу́л'ба.

Інші назви мають залежний іменник із прийменником у таких відмінках: 1) орудний відмінок із прийменником з (із). У такому разі залежний іменник вказує на обов'язковий компонент нової страви, який робить її унікальною (начинка чи намазка): картопл'а́ники з гриба́ми, ту́шана капу́ста з ри́сом, боршч з бобо́м, боршч з чавйухо́м, п’іроги́ з капу́стойу (n'ip'íz з капу́стойу), пироги́ з пас'о́луйу, п'ірог'е́ з йа́блуками; 2) родовий відмінок із прийменником з (із). Такі словосполучення являють собою поєднання назви страви із назвою продукту, який є їі основним інгредієнтом: п’іроги́ з карто́nли, боршч 3 ки́слойі капи́сти, боршч 3 бур'ако́войі нати́ни, боршч з либ'іди́, боршч з нате́ни, варе́н':а з тройа́ндових пел'у́сток, компо́m з черему́хи, кампо́m з йе́гуд; 3) місцевий відмінок із прийменниками у (в): карто́пл'a в лушпи́н':i, карто́пли в лушпа́і̌ках, карто́пле в мунд'і́рах, бу́л'ба в мунд'і́рах.

Зафіксовано кілька найменувань, які містять три та більше компоненти. Серед них - трикомпонентні структури, які поділяються на два типи: 1) ускладнення опорного двоскладного словосполучення залежним компонентом: ти́шана капу́ста з ри́сом; 2) опорний компонент однослівна назва страви має залежний компонент, виражений іменниковоприкметниковим словосполученням: боршч з ки́слойі капу́сти, боршч 3 бур'ако́войі нати́ни, боршч з бурачка́ мулуде́к̌ого, варе́н':а з тройа́ндових пел'у́сток.

Проведений аналіз структурних типів гастрономенів засвідчує, що більшість із них $\epsilon$ полілексемними, серед яких переважають двокомпонентні назви, що дає змогу посилити інформативність найменування.

Мотиваційні зв'язки проступають у значній кількості назв. Якщо згрупувати всі ці мотиви, то виявиться 2 основні семантичні моделі, за якими відбувається переосмислення:

1) 'продукт' $\rightarrow$ 'страва', напр.: гре́чка, горо́х, ре́с;

2) 'кулінарний процес або дія' $\rightarrow$ 'страва', напр.: ту́шана карто́nл'a, жа́рана карто́пл'а, бу́л'ба запе́чана, карто́пли ва́рани; 
Висновки та перспективи досліджень. Гастроназви утворюють розгалужену щодо репертуару тематичну групу лексики. Встановлено поліфункціональність одних номенів і монофункціональність інших. 3'ясовано, що за структурою більшість найменувань $\epsilon$ полілексемами; лексична варіативність номінацій зумовлена такими чинниками: реалізацією різних мотиваційних ознак при номінаціях, внутрішньоговірковими трансформаціями в межах номінацій; семантичні деривати $€$ наслідком метонімічного та метафоричного перенесень.

Для досліджуваної тематичної групи лексики визначальними $є$ такі диференційні ознаки: 'основний інгредієнт', 'спосіб приготування'. Спільною для всіх досліджуваних лексико-семантичних підгруп $\epsilon$ така мотиваційна модель - 'інгредієнт' $\rightarrow$ 'назва страви', яка реалізована за допомогою суфіксальної деривації, метонімії, аналітичної номінації, вираженої атрибутивними та субстантивними словосполученнями.

\section{Список обстежених населених пунктів}

м. Березне Березнівського району Рівненської області

с. Борбин Млинівського району Рівненської області

с. Брониця Камінь-Каширського району Волинської області

с. Видерта Камінь-Каширського району Волинської області

c. Воєгоща Камінь-Каширського району Волинської області

с. Волиця Камінь-Каширського району Волинської області

с. Воля Любешівського району Волинської області

с. Ворокомле Камінь-Каширського району Волинської області

с. Грудки Камінь-Каширського району Волинської області

с. Гряди Іваничівського району Волинської області

с. Дольськ Турійського району Волинської області

с. Залізниця Любешівського району Волинської області

с. Зарічне Зарічнянського району Рівненської області

с. Кадище Ківерцівського району Волинської області

м. Камінь-Каширський Камінь-Каширського району Волинської області

м. Ківерці Ківерцівського району Волинської області

с.Княгининок Луцького району Волинської області

с. Колодеже Горохівського району Волинської області

с. Луків Турійського району Волинської області

м. Любомль Любомльського району Волинської області

с. Майдан-Липненський Маневицького району Волинської області

с. Мар'янівка Горохівського району Волинської області

с. Мельники Шацького району Волинської області

с. Несвіч Луцького району Волинської області

с. Носарево Млинівського району Рівненської області

с. Окачеве Ратнівського району Волинської області

с. Осівці Камінь-Каширського району Волинської області

с. Підцаревичі Маневицького району Волинської області

с. Піщане Камінь-Каширського району Волинської області

с. Пнівне Камінь-Каширського району Волинської області

с. Погулянка Маневицького району Волинської області

смт Ратне Ратнівського району Волинської області

с. Ратнів Луцького району Волинської області 
с. Рудня Костопільського району Рівненської області

с. Самари Ратнівського району Волинської області

с. Світязь Шацького району Волинської області

с. Соснівка Камінь-Каширського району Волинської області

c. Сошичне Камінь-Каширського району Волинської області

с. Старий Чорторийськ Маневицького району Волинської області

с. Стенжаричі Володимир-Волинського району Волинської області

c. Тинне Сарненського району Рівненської області

с. Торчин Луцького району Волинської області

с. Тур Ратнівського району Волинської області

с. Хотешів Камінь-Каширського району Волинської області

с. Чаруків Луцького району Волинської області

с. Щедрогір Ратнівського району Волинської області,

\section{Список використаної літератури}

Аркушин, Григорій. Словник західнополіських говірок. 2-ге вид. Луцьк, 2016.

Блинова, Ольга. «Лексическая мотивированость и некоторые проблемы региональной лексикологи». Вопросы изучения лексики русских народных говоров. Ленинград: Наука, 1972, с. 92-104.

Борис, Людмила. Динаміка тематичної групи лексики їжі та напоїв у буковинських говірках. Автореф. дис. ...канд. філол. наук: 10.02.01. Чернівці, 2015.

Вештарт, Галіна. «Назвы ежы». Лексіка Палесся у прасторы і часе. Мінск: Навука і тэхніка, 1971, с. 89-142.

Волошинова, Марина. Динаміка традиційної предметної лексики в украӥнських східнослобожанських говірках. Автореф. дис. ...кандид. філол. наук: 10.02.01. Луганськ, 2014.

Ганудель, Зузанна. Бытовая лексика украинских говоров Восточной Словакии: (Названия пищи, посуды и утвари). Автореф. дис. ...канд. филол. наук: 10.02.01. Ужгород, 1980.

Гоца, Еріка. Назви їжі й кухонного начиння в українських карпатських говорах. Автореф. дис. ...канд. філол. наук: 10.02.01. Ужгород, 2001.

Загнітко, Надія. Назви їжі, напоїв у східностепових говірках Донеччини. Автореф. дис. ...канд. філол. наук: 10.02.01. Донецьк, 2011.

Козирєва, Зінаїда. «Українська когнітосфера “їжа” як предмет лінгвістичного дослідження». Науковий вісник кафедри ЮНЕСКО Київського національного лінгвістичного університету. Серія Філологія - Педагогіка - Психологія, вип. 29, 2014, c. 48- 55.

Омельковець, Руслана. Словник ботанічної лексики західнополіських говірок. Луцьк, 2009.

Різник, Віра. Назви їжі та кухонного начиння в говірках надсянсько-наддністрянського суміжжя. Автореф. дис. ...канд. філол. наук: 10.02.01. Львів, 2017.

Словник української мови, за ред. І. К. Білодіда. В 11 т. Київ: Наукова думка, 1970-1980.

Турчин, Евгения. Лексика питания в украинских восточнополесских говорах. Автореф. дисс. ...канд. филол. наук: 10.02.01. Киев, 1990.

Шмелев, Д., Журавлев, А., Ермакова, О. и др. Способы номинации в современном русском языке. Москва: Наука, 1982. 


\section{References}

Arkushyn, Hryhorii. Slovnyk zakhidnopoliskykh hovirok. $2^{\text {nd }}$ ed. Lutsk, 2016.

Blinova, Ol'ga. "Leksicheskaja motivirovanost' i nekotorye problemy regional'noj leksikologi". Voprosy izuchenija leksiki russkih narodnyh govorov. Leningrad: Nauka, 1972, pp. 92104.

Boris, Liudmyla. The dynamic content of the thematic lexical group of food and beverages in Bukovyna patois. PhD Thesis Abstract. Chernivtsi, 2015.

Vjestart, Halina. "Nazvy jezy". Ljeksika Paljessja u prastory i casje. Minsk: Navuka i technika, 1971, pp. 89-142.

Voloshynova, Maryna. Dynamics of traditional subject vocabulary in Ukrainian East Slobozhanshchina dialects. PhD Thesis Abstract. Luhansk, 2014.

Ganudel', Zuzanna. Bytovaja leksika ukrainskih govorov Vostochnoj Slovakii: (Nazvanija pishhi, posudy i utvari). PhD Thesis Abstract. Uzhgorod, 1980.

Gotsa, Erika. Names of food and kitchen utensils in Ukrainian Carpathian patoises. PhD Thesis Abstract. Uzhgorod, 2001.

Zahnitko, Nadiia. Names of Food and Drinks in Eastern Steppe Dialects of the Donetsk region. PhD Thesis Abstract. Donetsk, 2011.

Kozyrieva, Zinaida. "Ukrainska kohnitosfera "izha" yak predmet linhvistychnoho doslidzhennia". Naukovyi visnyk kafedry YuNESKO Kyivskoho natsionalnoho linhvistychnoho universytetu. Seriia Filolohiia - Pedahohika - Psykholohiia, iss. 29, 2014, pp. 48-55.

Omelkovets, Ruslana. Slovnyk botanichnoi leksyky zakhidnopoliskykh hovirok. Lutsk, 2009.

Riznyk, Vira. The names of foodstuffs and kitchen utensils in the Ukrainian dialects of the SanDniester region. PhD Thesis Abstract. Lviv, 2017.

Slovnyk ukrainskoi movy, edited by I. K. Bilodid. 11 vols. Kyiv: Naukova dumka, 1970-1980.

Turchin, Evgenija. Leksika pitanija $v$ ukrainskih vostochnopolesskih govorah. PhD Thesis Abstract. Kiev, 1990.

Shmelev, D., Zhuravlev, A., Ermakova, O. and all. Sposoby nominacii v sovremennom russkom jazyke. Moskva: Nauka, 1982. 